\title{
Soybean Cultivar, "Choseon" : \\ Cultivar with Yellow Medium Seed Size and Lipoxygenase 2,3 Protein-free
}

\author{
Jong Il Chung* \\ Department of Agronomy, Research Institute of Life Science, Gyeongsang National University, Chinju 660-701, \\ Korea
}

\begin{abstract}
Soybean [Glycine max (L.) Merr.] is an important source for protein, oil, carbohydrates, isoflavones, and many other nutrients to humans and animals. Lipoxygenase protein is the main antinutritional factor in mature soybean seed. Soybean cultivar, "Choseon" with yellow medium seed size and free of lipoxygenase 2,3 protein was developed. "Choseon" was selected from the population derived from the cross between cultivar, "Jinpum 2" and germplasm, PI408155. "Choseon" has purple flowers, tawny pubescence, a determinate growth habit, and light yellow pods at maturity. The seed of "Choseon" has yellow hilum and yellow seed coat color. Seed protein and oil content on a dry weight basis were 34.2 and $16.9 \%$, respectively. "Choseon" has shown a resistant reaction to soybean necrosis, soybean mosaic virus, Cercospora leaf spot and blight, black root rot, pod and stem blight, and bacterial pustule. "Choseon" matured in 5 October with plant height of $51 \mathrm{~cm}$ and a 100 -seed weight of $15.1 \mathrm{~g}$. Average yield of "Choseon" was 2.66 (Ton/ha) on the regional yield trials of 2013 at 4 locations. "Choseon" has been registered as a soybean cultivar (registration number: 5985, registration date: April 11, 2016) by Korea Seed \& Variety Service, Republic of Korea.
\end{abstract}

Keywords : Soybean, Choseon, Lipoxygenase, Yellow seed, Medium seed size

\section{INTRODUCTION}

Soybean [Glycine max (L.) Merr.] is widely grown for food and feed products. Demand of soybean products has increased by high quality of protein with essential amino acids, vitamins, fibre, essential fatty acids, phytochemicals, and lecithins (Obendorf et al. 2008). Lipoxygenase protein is the major antinutritional factor in mature soybean seeds. End-products of lipoxygenase activity are converted to many volatile compounds, which are responsible for the beany flavor associated with soybean products. In soybean seeds, lipoxygenase proteins constitute about $1-2 \%$ of the protein. Lipoxygenase protein can be isolated as three isoenzymatic forms. Lipoxygenase proteins are controlled by single dominant genes i.e. $L x 1, L x 2$ and $L x 3$, while absence is ascribed to corresponding recessive alleles $(l x l, l \times 2, l \times 3)$. The studies on inheritance and genetic elimination of lipoxygenase protein

\footnotetext{
*Corresponding Author (E-mail: jongil@gnu.ac.kr, Tel: +82-055772-1872)
}

(Received on March 6, 2017. Accepted on April 3, 2017.) were reported (Hildebrand \& Hymowitz 1981, Davies \& Nielsen 1986, Kitamura et al. 1983). Genotypes with lipoxygenase free are better accepted due to production of very low levels of hexanal compounds (Kobayashi et al. 1995). Heat inactivation of the lipoxygenase at industrial level not only incurs extra cost but also affects the solubility and functionality of proteins (Macleod \& Ames 1988). Development of genotypes with lipoxygenase free through genetic elimination is the key to get rid of the beany-flavour. So far, a few cultivars with lipoxygenase protein free have been developed (Kim et al. 1997, Chung 2009). However, soybean cultivars with yellow medium seed size and free of lipoxygenase protein for use as sprout or natto were not released. Soybean cultivar with yellow medium seed size and free of lipoxygenase 2,3 protein was developed.

\section{MATERIALS AND METHODS}

Two parents were used to improve new lines with traits of yellow seed coat, medium seed size, and free of lipoxygenase 2,3 protein. The Cultivar, "Jinpum 2" used as 


\begin{tabular}{|c|c|c|c|c|c|c|c|c|}
\hline Year & '03 & '04 & '05-'06 & '07-'09 & '10 & '11 & '12 & '13 \\
\hline \multirow[t]{4}{*}{ Generation } & Crossing & $\mathrm{F}_{2}$ & $F_{3-4}$ & $\mathrm{~F}_{5}-\mathrm{F}_{7}$ & $\mathrm{~F}_{8}$ & $\mathrm{~F}_{9}$ & $\mathrm{~F}_{10}$ & \\
\hline & Jinpum 2 & 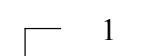 & - & 1 & 1 & & & \\
\hline & PI408155 & $\cdot$ & . & . & 4 & Bulk & Bulk & Choseon \\
\hline & & ᄂ 300 & 20 & 11 & & & & \\
\hline Procedure & Crossing & Seed analys & is selection & Line $s$ & ion & $\mathrm{PYT}^{\mathrm{z})}$ & $\mathrm{AYT}^{\mathrm{y})}$ & $\mathrm{RYT}^{\mathrm{x})}$ \\
\hline
\end{tabular}

Fig. 1. Pedigree diagram of "Choseon". ${ }^{\mathrm{z})}$ : Preliminary yield trial, ${ }^{\mathrm{y})}$ : Advanced yield trial, ${ }^{\mathrm{x})}$ : Regional yield trial.

Table 1. Qualitative characteristics of Choseon.

\begin{tabular}{cccccccc}
\hline Cultivar & $\begin{array}{c}\text { Growth } \\
\text { habit }\end{array}$ & $\begin{array}{c}\text { Flower } \\
\text { color }\end{array}$ & $\begin{array}{c}\text { Leaf } \\
\text { shape }\end{array}$ & $\begin{array}{c}\text { Pubescence } \\
\text { color }\end{array}$ & $\begin{array}{c}\text { Seed coat } \\
\text { color }\end{array}$ & $\begin{array}{c}\text { Hilum } \\
\text { color }\end{array}$ & $\begin{array}{c}\text { Cotyledon } \\
\text { color }\end{array}$ \\
\hline Choseon & Determinate & Purple & Oval & Tawny & Yellow & Yellow & Yellow \\
Pungsannamulkong & Determinate & Purple & Oval & Tawny & Yellow & Yellow & Yellow \\
\hline
\end{tabular}

female has traits of yellow seed coat, little large seed size $(23.5 \mathrm{~g} / 100 \mathrm{seed})$, and free of lipoxygenase $1,2,3$ protein (Kim et al. 1997). Soybean germplasm, PI408155 used as male parent has yellow seed coat, small seed size $(6.6 \mathrm{~g} / 100$ seed) and lipoxygenase protein-present. F1 seeds from the cross were obtained and were planted at greenhouse in 2003. Presence or absence of lipoxygenase protein in each of the $F_{2}$ seed was tested by SDS-PAGE protein analysis (Sathe 1991). $F_{2}$ seeds were planted in May 2004. Single $F_{2}$ plants were harvested based on plant type, height and maturity. Tweenty lines with lipoxygenase 2,3 protein free were planted and harvested in 2005 and 2006. Pedigree selection method was used through $F_{5}$ and $F_{7}$ generation to select plants with yellow seed coat, medium seed size and free of lipoxygenase 2, 3 protein. One $F_{8}$ line with acceptable agronomical traits such as flowering date, maturity date, growth habit, plant type, lodging and seed quality was selected in 2010. Qualitative traits were recorded in 2011 and 2012 at Jinju location. Agronomic traits such as lodging, shattering and reaction to disease were recorded according to standard soybean cultivation manual of RDA, Korea. Yield, protein and oil content, and insect resistance were tested in Korea Seed \& Variety Service. Selection procedures are shown in Figure 1 .

\section{RESULTS AND DISCUSSION}

\section{Agronomic performance}

Qualitative traits of "Choseon" are shown in Table 1. "Choseon" has purple flowers, tawny pubescence, a determinate growth habit, oval leaflet shape, and light yellow pods at maturity. The seed of "Choseon" has yellow hilum and yellow seed coat color. Cotyledon color of mature seed is yellow.

Quantative traits of "Choseon" are shown in Table 2. "Choseon" flowered in August 1, which is 2 days earlier than "Pungsannamulkong". "Choseon" matured in October 3, which is 2 days earlier than "Pungsannamulkong". Plant 
Table 2. Quantitative characteristics of Choseon determined by regional yield trial in 2013 .

\begin{tabular}{ccccccc}
\hline Cultivar & $\begin{array}{c}\text { Flowering } \\
\text { date }\end{array}$ & $\begin{array}{c}\text { Maturity } \\
\text { date }\end{array}$ & $\begin{array}{c}\text { Plant } \\
\text { height }(\mathrm{cm})\end{array}$ & $\begin{array}{c}\text { Lodging }^{\text {Z) }} \\
(0-9)\end{array}$ & $\begin{array}{c}100 \text {-seed } \\
\text { weight }(\mathrm{g})\end{array}$ & $\begin{array}{c}\text { Shattering } \\
(0-9)\end{array}$ \\
\hline Choseon & August 1 & Oct. 3 & $51 \pm 1.2 \mathrm{a}^{\mathrm{x})}$ & 0 & $15.1 \pm 0.68 \mathrm{a}^{\mathrm{x})}$ & 3.0 \\
Pungsannamulkong & August 3 & Oct. 5 & $62 \pm 2.7 \mathrm{~b}$ & 1 & $12.3 \pm 0.12 \mathrm{~b}$ & 2.5 \\
\hline
\end{tabular}

Z) 0: not lodged, 9:completely lodged.

Y) 0: no shattering, 9:completely shattering.

x) Mean \pm Standard Error, different letters in the column are significantly different by DMRT at $5 \%$.

Table 3. Yield of Choseon on the regional yield trials of 2013 at 4 locations.

\begin{tabular}{ccc}
\hline Location & Choseon (Ton/ha) & Pungsannamulkong (Ton/ha) \\
\hline Jinju & 2.80 & 2.90 \\
Sachun & 2.70 & 2.85 \\
Miryang & 2.65 & 2.92 \\
Muan & 2.50 & 2.70 \\
Mean & 2.66 & 2.84 \\
\hline
\end{tabular}

${ }^{\mathrm{ns}}$ : Not significant

Table 4. Characterics for seed components of Choseon estimated in 2013 at Miryang.

\begin{tabular}{cccc}
\hline Cultivar & Crude protein (\%) & Crude oil (\%) & Lipoxygenase 2,3 protein \\
\hline Choseon & 34.2 & 16.9 & Absent \\
Punsangnamulkong & 35.0 & 18.1 & present \\
\hline
\end{tabular}

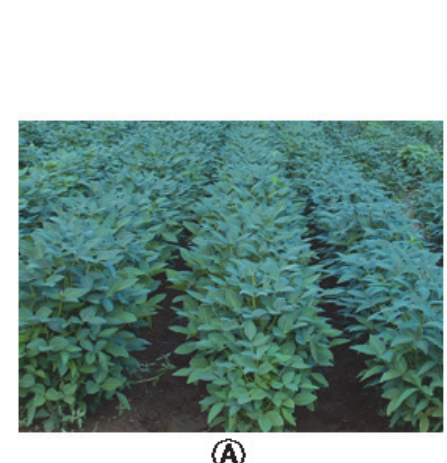

(A)

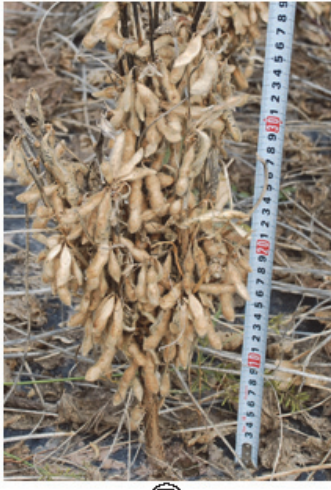

(B)

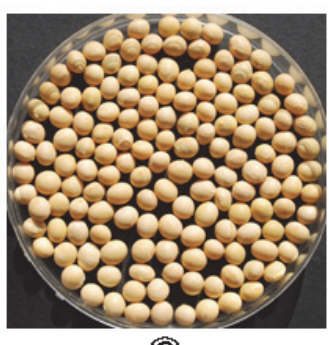

(C)

Fig. 2. Phenotype of Choseon cultivar. (A): appearance of V6 stage in field, B): appearance of R8 stage in field, (C): seed of harvested.

height of "Choseon" was $51 \mathrm{~cm}$ compared to the check cultivar of $62 \mathrm{~cm}$. Lodging score of "Choseon" was 0 . The 100-seed weight of "Choseon " was 15.1 g larger than that of "Pungsannamulkong"(12.3 g). "Choseon" had a shattering score of 3.0 versus "Pungsannamulkong" with a score of 2.5. Average yield of "Choseon" (Jinju location) was 2.7
- 2.9 ton/ha in $2012-2013$.

Yield of "Choseon" was shown in Table 3. Average yield of "Choseon" was 2.66 (Ton/ha) on the regional yield trials of 2013 at 4 locations.

Traits for seed components of "Choseon" are shown in Table 4. Average seed protein and oil content on a dry weight 
Table 5. Resistant degree of Choseon to soybean disease estimated in 2013.

\begin{tabular}{cccccc}
\hline Cultivar & $\begin{array}{c}\text { Necrosis } \\
(0-9)\end{array}$ & $\begin{array}{c}\text { Mosaic } \\
\text { virus } \\
(0-9)\end{array}$ & $\begin{array}{c}\text { Cercospora leaf spot } \\
\text { and blight (0-9) }\end{array}$ & $\begin{array}{c}\text { Black } \\
\text { root rot } \\
(0-9)\end{array}$ & $\begin{array}{c}\text { Pod and } \\
\text { stem light } \\
(0-9)\end{array}$ \\
\hline Choseon & 0 & 0.5 & 2 & 0 & $\begin{array}{c}\text { Bacterial } \\
\text { pustule } \\
(0-9)\end{array}$ \\
Pungsannamulkong & 0 & 1.0 & 2 & 0 & 1 \\
\hline Z) 0: Resistant, 9: susceptible. & & & &
\end{tabular}

basis were $34.2 \%$ and $16.9 \%$, respectively compared to $35.0 \%$ and $18.1 \%$ of the check cultivar, "Pungsannamulkong". Lipoxygenase 2, 3 protein was absent in "Choseon", but was present in "Pungsannamulkong".

Plants and seeds of "Choseon" are shown in Figure 2.

\section{Disease Resistance}

Reaction of "Choseon" to soybean diseases is shown in Table 5. "Choseon" was resistant to soybean necrosis similar to check cultivar (0 score). Also, both cultivars "Choseon" and "Pungsannamulkong" were resistant to soybean mosaic. "Choseon" was resistant to Cercospora leaf spot and blight, black root rot, pod and stem blight. Score of resistance to Bacterial pustule in "Choseon" was higher than "Pungsannamulkong" with a score of 0 and 1 , respectively.

\section{REFERENCES}

1. Chung JI. 2009. A new cultivar "Gaechuck\#1": black soybean cultivar with lipoxygenase2,3-free, Kunitz trypsin inhibitor-free and green cotyledon. Korean J. Breed. Sci. 41(4): 603-606.

2. Chung JI. 2009. A new cultivar "Gaechuck\#2": yellow soybean cultivar with lipoxygenase2,3-free, Kunitz trypsin inhibitor-free. Korean J. Breed. Sci. 41(4): 612-615.

3. Davies CS, Nielsen SS. 1986. Genetic analysis of a null-allele for lipoxygenase -2 in soybean. Crop Sci. 26: 460-462.

4. Hildebrand DF, Hymowitz T. 1981. Soybeans lacking lipoxygenase. J. Am. oil Chem. Soc. 58: 583-586.

5. Kim SD, Kim YH, Park KY, Yun HT, Lee SH, Lee YH, Seung YK, Kim HS, Hong EH, Kim YS. 1997. A new beany tasteless soybean variety "Jinpumkong 2" with good quality. Korean J. Breed. 29(4): 502.

6. Kitamura K, Davies CS, Kaizuma N, Nielsen NC. 1983. Genetic analysis of a null-allele for lipoxygenase-3 in soybean seeds. Crop sci. 58: 583-586.

7. Kobayashi AT, Hirata N, Kubota K, Kitamura. 1995. Aroma constituents of soybean milk lacking lipoxygenase isozymes. J Agri Food Chem 43: 2449-2452.

8. MaCleod G, Ames J. 1988. Soya flavor and its improvement. CRC Crit Rev Food Sci Nutr 27: 219-400.

9. Obendorf RL, Zimmerman AD, Ortiz PA, Taylor AG, Schnebly SR. 2008. Imbibitional chilling sensitivity and soluble carbohydrate composition of low raffinose, low stachyose soybean seed. Crop Sci. 48: 2396-2403.

10. Sathe SK. 1991. Isolation and characterization of the protein that copurifies with soybean (Glycine max L.) glycinin. J. Food Biochem.15: 33-49. 